\title{
PENGARUH HORMON GIBERELIN TERHADAP VIABILITAS BENIH STROBERI (Fragaria x Ananassa)
}

\section{THE EFFECT OF GIBBERELLINE HORMONE TO THE VIABILITY OF STRAWBERRY SEED (Fragaria $x$ Ananassa)}

\author{
Larin Tikafebianti $1^{*}$, Gita Anggraeni2, Ratna Dwi Hirma Windriati ${ }^{3}$ \\ 1,2,3Program Studi Agroteknologi, Universitas Nahdlatul Ulama Purwokerto
}

*Korespondensi: ibulalin@gmail.com

\begin{abstract}
ABSTRAK
Keters ediaan bibit yang baik masih menjadi kendala utama dalam pengembangan budi daya stroberi di Indonesia. Perbanyakan bibit stroberi umumnya dilakukan dengan memisahkan stolon, namun teknik ini memiliki kelemahan karena bibit asal stolon rentan membawa penyakit dari indukan. Salah satu alternatif perbanyakan bibit stroberi adalah dengan cara me numbuhkan tanaman baru dari biji. Biji yang baik adalah yang memiliki viabilitas benih tinggi. Pemberian hormon eksogen seperti giberelin diduga mampu memperbaiki viabilitas benih. Penelitian ini bertujuan untuk mengetahui pengaruh pemberian hormon giberelin terhadap viabilitas benih stroberi. Penelitian ini dilaksanakan dengan menggunakan metode eksperimental Rancangan Acak kelompok (RAK) dengan perlakuan berupa taraf hormon giberelin $(0 ; 50 ; 100 ; 150$ dan $200 \mathrm{ppm})$, yang direndamkan pada biji stroberi selama 2 x 24 jam. Variabel yang diamati adalah daya berkecambah (\%), potensi tumbuh maksimum (\%) dan index vigor (\%). Hasil penelitian, menunjukan bahwa daya berkecambah dan index vigor perlakuan $100 \mathrm{ppm}$ giberelin mencapai hasil tertinggi yaitu: 7,3\% dan 2,67 \%. Sem entara pada variabel potensi tumbuh maksimum (PTM), semakin tinggi taraf perlakuan justru PTM semakin rendah, sehingga disimpulkan bahwa pemberian giberelin dapat meningkatkan daya berkecambah dan indeks vigor benih, nam un tidak dapat meningkatkan PTM.
\end{abstract}

Kata kunci: Stroberi, giberelin, viabilitas, vigor, benih.

\begin{abstract}
The availability of good quality of Strawberry seed is still being a main problem in the strawberry cultivation in Indonesia. The propagation of strawberry plant is commonly done by separating stolons from the parent, but this methode has a disadvantage because the new plant from stolonis susceptible to carry pathogen. Another alternative in multiplying strawberry is to grow strawberry from the seeds. The good seeds are those that have high viability. Gibbereline hormone is assumed to be able to improve the viability of seeds. The study aims to evaluate the effect of gibbereline hormone to the viability of strawberry seeds. The research was carried out using an experimental method of Randomized Block Design (RBD).The treatments of research was the addition of gibbereline hormone lev el $0 ; 50 ; 100 ; 150 ; 200$ PPM which are soaked to strawberry seed for $2 \times 24$ hours. The observed variables were the energy of germination (\%), maximum growth potential (\%), and vigor index (\%). The result of study showed that the germinating energy and the vigor treatment index of $100 \mathrm{ppm}$ gibberellins achieved the highest results in 7,3\% and 2, $67 \%$. While the maximum growth potential (PTM) showed that the higher gibbereline dose gets the maximum growth potential (PTM) lower. It was concluded that the gibbereline is able to increase energy of germination and vigor index but it is not able to increasethe maximum growth potential.
\end{abstract}

Keyword: Strawberry, gibbereline, viability, vigor, seed 


\section{PENDAHULUAN}

Stroberi (Fragaria $x$ Ananassa) adalah tanaman buah subtropis asal chili, Amerika Latin. Selain bentuknya yang lucu, manfaat dari buah stroberi membuat banyak orang berminat untuk mengkonsumsinya, baik sebagai buah segar maupun sebagai garnish (hiasan untuk makanan). Meskipun stroberi berasal dari daerah sub tropis, namun stroberi dapat ditumbuhkan pada rentang geografis yang luas, mulai dari daerah tropika hingga ke daerah artic (Hancock, 1999).

Stroberi dapat diperbanyak dengan biji maupun benih vegetatif seperti: anakan, stolon, atau akar sulur (Hanif Z, 2015). Namun demikian ketersediaan bibit yang baik masih menjadi kendala utama dalam pengembangan budi daya stroberi.

Mendatangkan bibit impor dari luar negeri dengan harga tinggi membutuhkan modal yang besar sehingga petani memilih memperbanyak bibit dengan cara membiakkan stolon dari indukan yang berumur 1-2 tahun, atau dengan cara memisahkan anakan dari indukan potensial. Perbanyakan dengan cara ini memiliki banyak kelemahan, diantaranya: volume perbanyakan sedikit, bibit rentan terserang penyakit yang diturunkan oleh induk dan dapat menurunkan kualitas hasil buah (Zebrowska, 2004).

Kelemahan perbanyakan bibit secara vegetatif akan merugikan petani stroberi. Karena itu diperlukan teknologi baru dalam teknik perbanyakan stroberi, misalnya dengan menumbuhkan bibit dari biji yang berasal dari buah. Menanam dari biji memiliki kelebihan seperti: tanaman yang dihasilkan lebih kuat dan sehat, umur tanaman akan lebih lama, harga bibit menjadi lebih murah, dan memperluas variasi genetik dari induknya. Meskipun begitu, menanam dari biji masih enggan dilakukan oleh petani karena biji stroberi termasuk jenis biji yang memiliki masa dormansi lama dan sulit berkecambah dalam waktu singkat (Bewley dan Black, 1982). Hamdouni (2001) melaporkan, perlakuan pemotongan achenes dapat mempercepat proses viabilitas biji stroberi yang ditanam dalam kultur. Sementara Suman Lata, et al (2018), melaporkan bahwa biji stroberi varietas Axbridge early yang diberi perlakuan hormon gibereline $\left(\mathrm{GA}_{3}\right)$ dapat meningkat jumlah dan kecepatan viabilitasnya.

Viabilitas benih adalah daya berkecambah dari biji yang menunjukkan daya hidup benih. Biji yang berkecambah menunjukkan proses metabolisme dalam biji tersebut aktif. Sedangkan metabolisme dipengaruhi oleh enzim dan zat pengatur tumbuh (hormon) indogen yang terdapat dalam biji dalam jumlah sangat sedikit. Penggunaan Zat Pengatur Tumbuh seperti Gibereline (1200 ppm) dan teknik stratifikasi (15 minggu) dilaporkan oleh Demirsoy, et al (2010), dapat meningkatkan persentase viabilitas biji stroberi genotip Arbutus Unedo. Sementara itu, Arda dkk (2014) melaporkan, perlakuan $\mathrm{GA}_{3}$ yang dikombinasikan dengan taraf stratifikasi berpengaruh nyata pada panjang kecambah stroberi di akhir pengamatan. Semantara itu, 
belum ada yang melaporkan tentang pengaruh giberelin terhadap viabilitas benih, potensi tumbuh maksimum dan index vigor pada stroberi.

\section{MATERI DAN METODE}

\section{MATERI}

Materi dari percobaan ini adalah biji stroberi yang telah dipisahkan dari buah segar.

\section{METODE}

\section{Pemisahan biji dari buah segar}

- $\quad$ Kulit stroberi disayat setipis mungkin untuk memisahkan biji dan buah.

- Sayatan tipis kulit dijemur di terik matahari selam 3 x 24 jam atau sampai kering maksimal.

- Biji stroberi dipisahkan dari kulit yang sudah kering dengan cara diusap kasar dengan jari.

- $\quad$ Rendam biji dalam masing- masing perlakuan selama 2 × 24 jam.

- Siapkan media tanam berupa wadah plastik yang diberi kapas basah

- Semai biji pada permukaan kapas, lalu tutup wadah untuk menjaga kelembabannya dan tutup dengan plastik berwarna hitam.

Beri tambahan air setiap 3 hari sekali untuk menjaga kelembaban media sampai biji berkecambah

\section{Pembuatan larutan}

Pembuatan larutan hormon giberelin 0, 50, 100, 150, dan 200 ppm sebagai taraf perlakuan dibuat dengan rumus:

$M_{1} \cdot V_{1}=M_{2} . V_{2}$

sehingga didapatkan:
0 ppm $\mathrm{GA}_{3}=0 \mathrm{ml} \mathrm{GA} 3$ dalam

$100 \mathrm{ml}$ aquades

- $50 \mathrm{ppm} \mathrm{GA} 3=50 \mathrm{ml} \mathrm{GA} 3$ dalam $100 \mathrm{ml}$ aquades

- 100 ppm GA $=100 \mathrm{ml} \mathrm{GA}_{3}$ dalam $100 \mathrm{ml}$ aquades

- 150 ppm GA3 $=150 \mathrm{ml} \mathrm{GA}_{3}$ dalam $100 \mathrm{ml}$ aquades

- $200 \mathrm{ppm} \mathrm{GA}_{3}=200 \mathrm{ml} \mathrm{GA}_{3}$ dalam $100 \mathrm{ml}$ aquades

\section{Variabel Pengamatan}

Potensi Tumbuh Maksimal/PTM (\%):

PTM $=\underline{\Sigma}$ benih yang tumbuh $\times 100 \%$ $\Sigma$ benih yang ditanam

Daya Berkecambah/DB(\%), berdasarkan Sutop (2002):

DB $=\Sigma$ KN hitungan ke-1 $+\Sigma$ KN hitungan ke-2: $\Sigma$ benih yang ditanam Indeks Vigor/IV (\%), berdasarkan ISTA (2010):

\section{IV $=(\Sigma$ kecambah normal pada hitungan} pertama x $100 \%$ ): $\Sigma$ benih yang ditanam

\section{HASIL DAN PEMBAHASAN}

Pada umumnya viabilitas benih diartikan sebagai kemampuan benih untuk tumbuh menjadi kecambah. Istilah lain untuk viabilitas benih adalah daya kecambah benih, persentase kecambah benih atau daya tumbuh benih.

Viabilitas benih dipengaruhi oleh zat pengatur tumbuh (zpt) atau hormon. ZPT 
adalah senyawa yang dihasilkan oleh tanaman dalam jumlah sangat kecil, namun mempengaruhi berbagai proses fisiologisnya. Sejumlah hormon eksogen/horm on buatan manusia juga biasa diaplikasikan pada tanaman untuk meningkatkan pertumbuhan dan perkembangan tanaman.

Hasil penelitian tentang Pengaruh Hormon Eksogen Terhadap

viabilitas benih stroberi (Fragaria $\mathrm{x}$ Ananassa) didapatkan hasil yang dijelaskan secara deskriptif melalui parameter:

\section{Potensi Tumbuh Maksimum/PTM (\%)}

Potensi tumbuh maksimum merupakan salah satu parameter viabilitas benih. Besarnya nilai PTM menunjukkan kondisi viabilitas benih yang tinggi.

Potensi tumbuh maksimum adalah persentase keseluruhan biji yang dapat berkecambah/ pecah masa dormannya dan menunjukan gejala hidup, baik menghasilkan kecambah normal maupun abnormal. Potensi tumbuh maksimum merupakan persentase dari jumlah biji berkecambah dibagi jumlah biji yang ditanam.

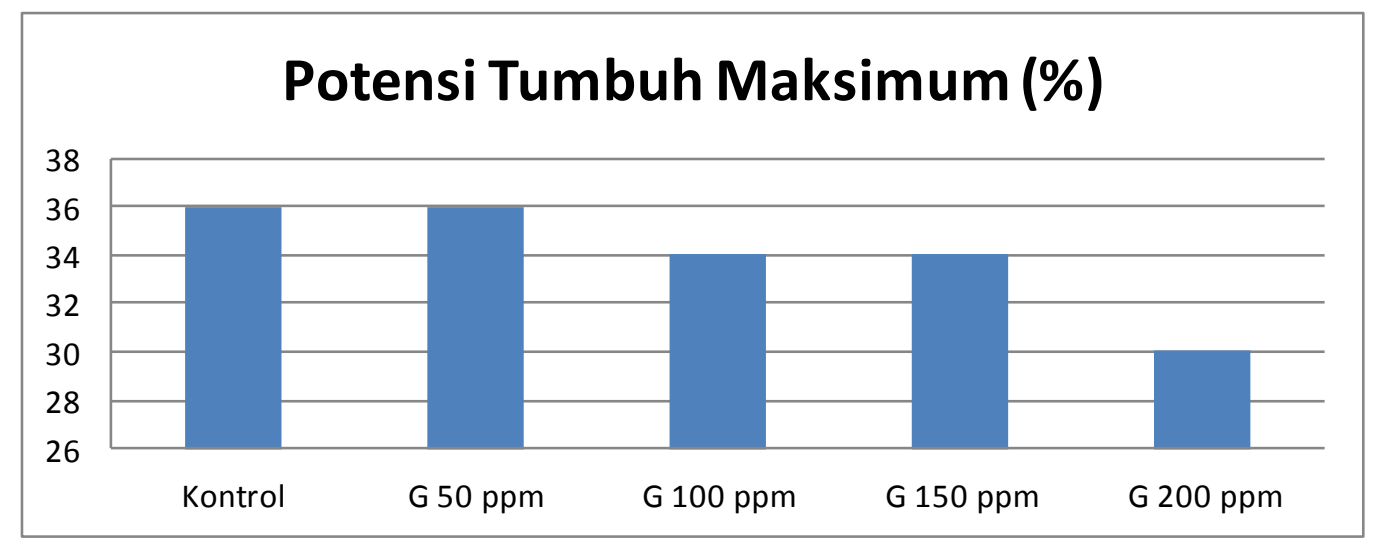

Gambar 1. Potensi Tumbuh Maksimum/PTM (\%) pada biji stroberi dengan perlakuan taraf giberelin

Dari hasil penelitian diketahui bahwa potensi tumbuh maksimum tertinggi (36\%) dihasilkan oleh perlakuan giberelin 50 ppm dan 0 ppm. Sementara perlakuan giberelin 200 ppm justru menunjukkan nilai potensi tumbuh maksimum paling rendah (30\%).

Kucera et al (2005) melaporkan bahwa giberelin dapat meningkatkan potensi tumbuh dari dari embrio dan dapat mengatasi hambatan mekanik dalam prkecambahan yang diakibatkan oleh lapisan penutup benih.

\section{INDEKS VIGOR}

Vigor benih yang tinggi dicirikan antara lain tahan disimpan lama, tahan terhadap serangan hama penyakit, cepat dan merata tumbuhnya serta mampu menghasilkan tanaman dewasa yang normal dan berproduksi baik dalam keadaan lingkungan tumbuh yang sub optimal. Nilai index vigor menggambarkan keseragaman dan kecepatan benih dalam berkecambah pada saat tertentu. Vigor menggambarkan kekuatan benih untuk tumbuh dalam kondisi 
sub optimum serta bebas dari mikroorganisme.

Dari penelitian ini diketahui bahwa perlakuan giberelin 100 ppm dan 150 ppm, nilai vigornya mencapai nilai tertinggi 2,67 $\%$. Sementara giberelin $0 \mathrm{ppm}$ dan giberelin
200 ppm mencapai $2 \%$ dan nilai terendah indeks vigor dicapai oleh giberelin 50 ppm. Devi Rusmin et al (2011) melaporkan bahwa giberelin 400 ppm dapat meningkatkan index vigor

purwoceng.

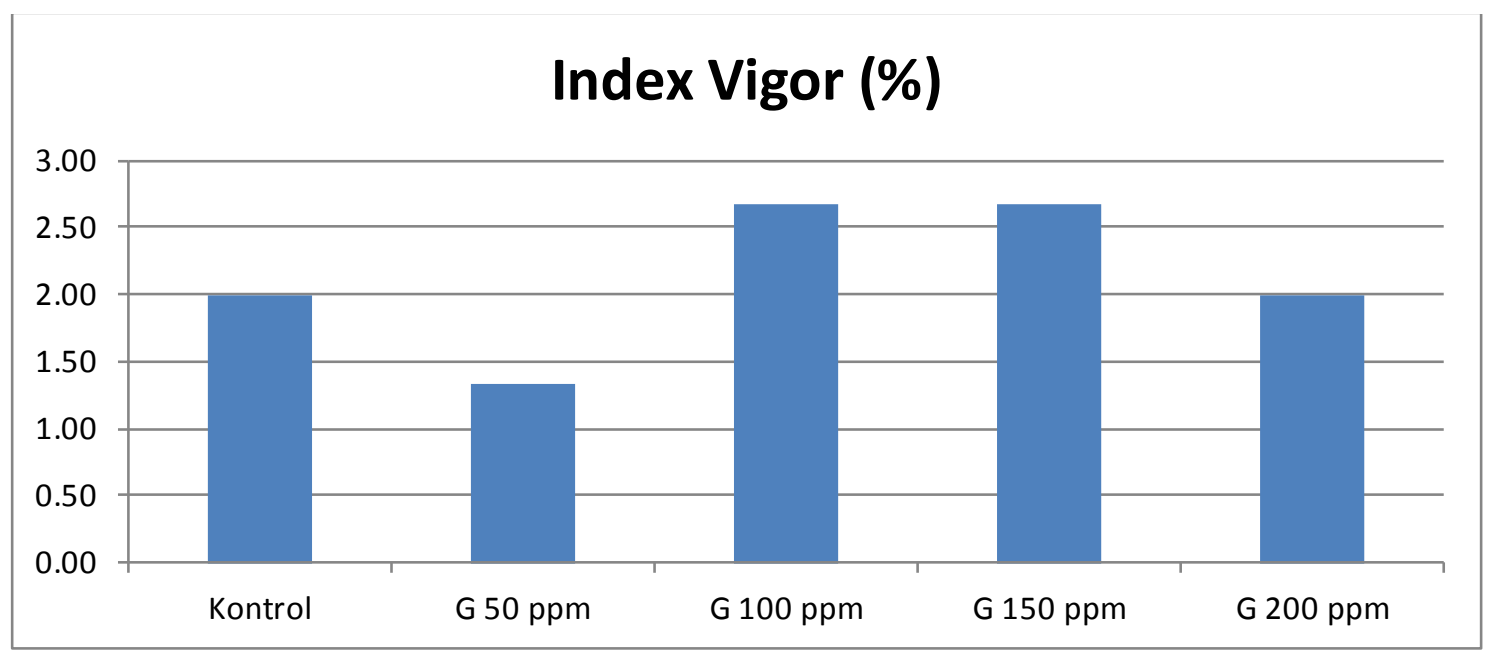

Gambar 2. Nilai indeks vigor pada biji stroberi dengan perlakuan taraf giberelin.

\section{DAYA BERKECAMBAH}

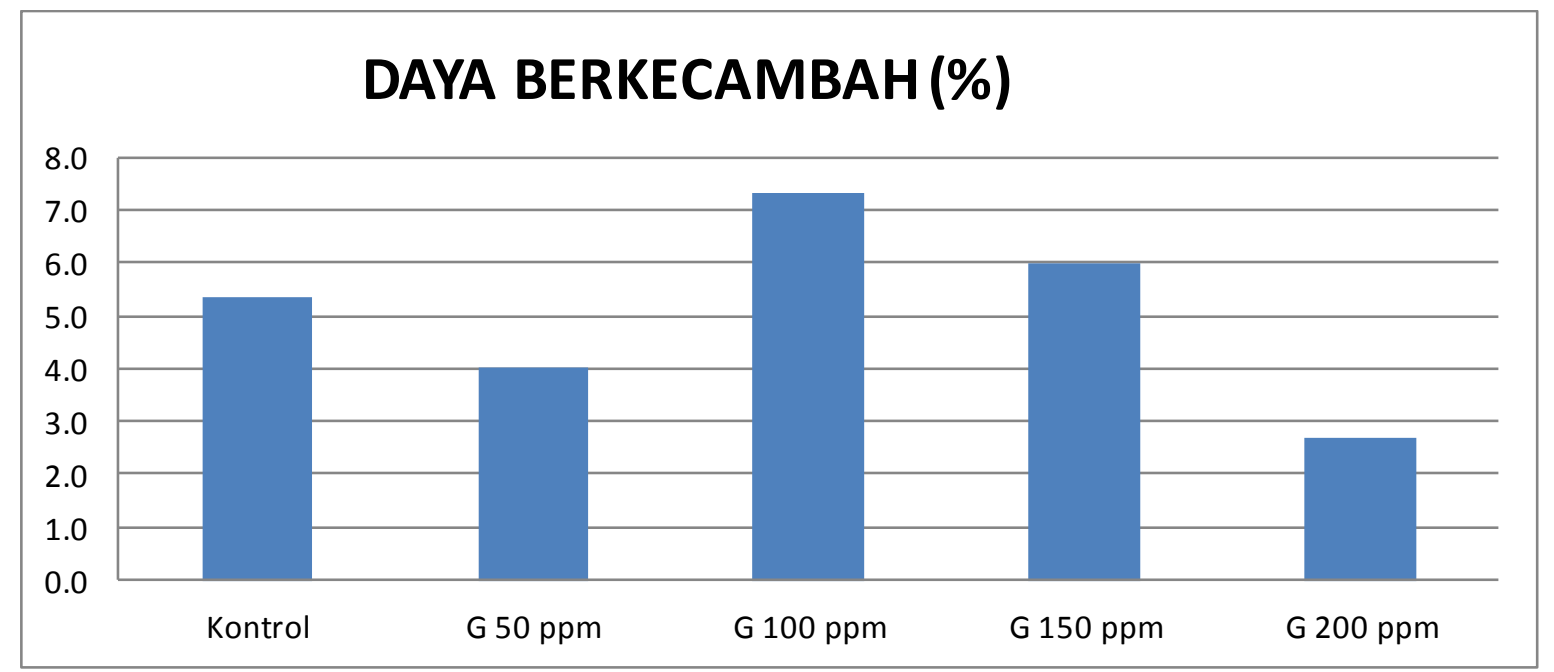

Gambar 3. Daya berkecambah pada biji stroberi dengan perlakuan taraf giberelin.

Dari hasil penelitian ini diketahui bahwa daya berkecambah paling tinggi diperoleh biji yang mendapat perlakuan giberelin dengan taraf 100 ppm sebesar 7,3\%, lalu 
diikuti oleh giberelin 150 ppm (6\%), giberelin 0 ppm (5, $3 \%$ ), giberelin 50 ppm (4 \%) dan giberelin 200 ppm (2,7\%). Wilkins (1978), meyatakan bahwa biji yang membutuhkan perlakuan dingin untuk memulai perkecambahannya dapat digantikan hanya dengan memberikan hormon dalam jumlah sedikit. Dari hasil penelitian ini, perlakuan giberelin 100 ppm menghasilkan daya berkecambah tertinggi (7, 3 \%). Hal ini diduga karena pada taraf 100 ppm, giberelin dapat mendorong fungsi fisiologis dalam biji stroberi ke arah perkecambahan dan mengurangi aktivitas ABA yang merupakan inhibitor perkecambahan, seperti yang dijelaskan Budiman dan Desi (2010).
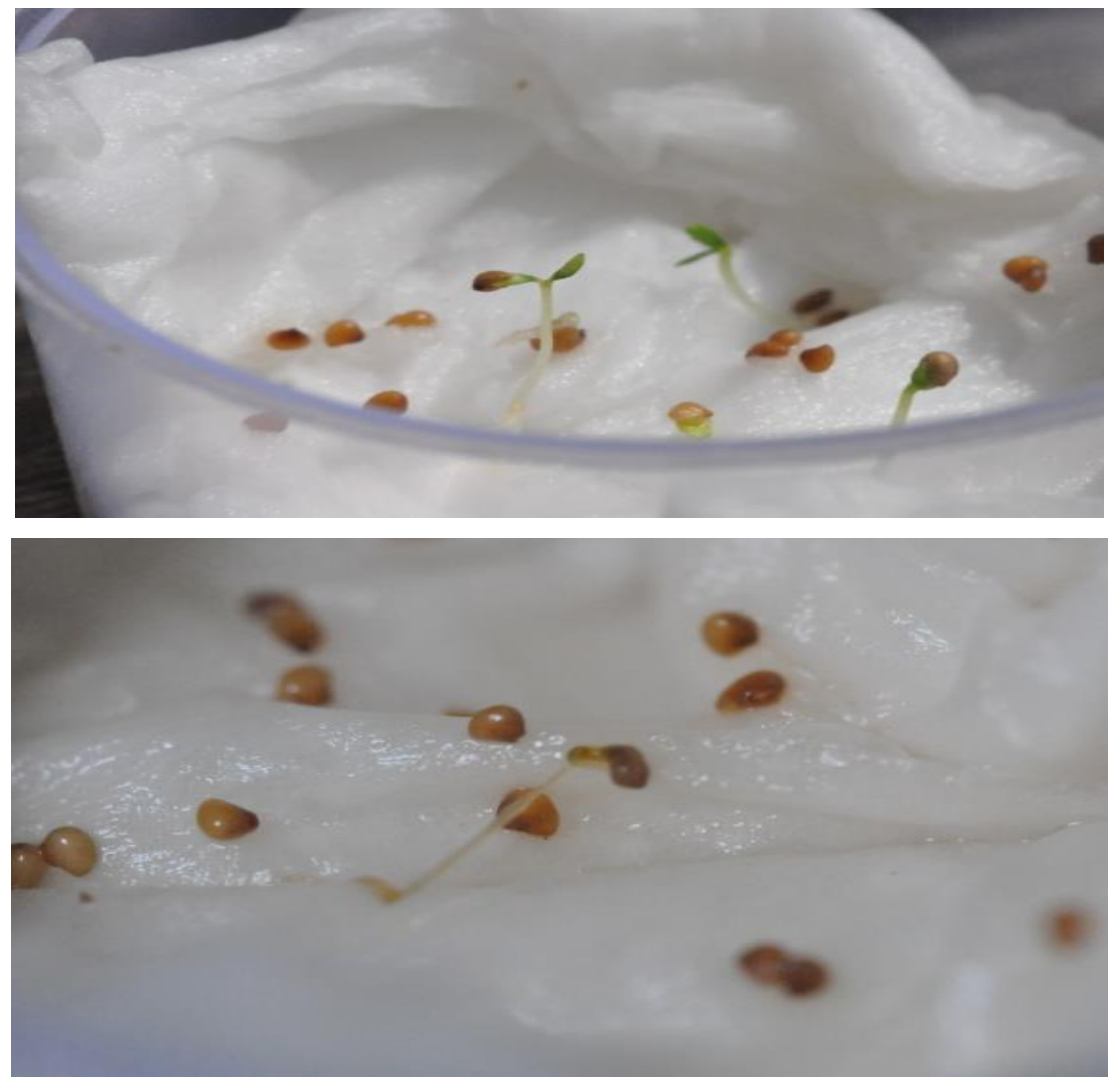

Gambar 4. Perbedaan kecambah stroberi normal (atas) dan abnormal (bawah).

\section{SIMPULAN}

Perlakuan perendaman biji stroberi dalam hormon eksogen giberelin dapat meningkatkan daya berkecam bah dan indeks vigor benih, namun tidak dapat meningkatkan potensi tumbuh maksimum.

\section{UCAPAN TERIMA KASIH}

Terima kasih disampaikan kepada LPPM Universitas Nahdlatul Ulama Purwokerto yang telah mendanai penelitian ini melalui skema Penelitian Dosen Pemula (PDP) bagi dosen di Universitas Nahlatul Ulama Purwokerto. 


\section{DAFTAR PUSTAKA}

Arda, M., Suwirmen \& Noli Z.A. 2014. Pengurangan masa stratifikasi dengan penambahan hormon $\mathrm{GA}_{3}$ pada viabilitas benih stroberi (Fragaria x Ananassa (Weston) Duchesne). Jurnal Biologi Universitas Andalas. ISSN 2303-2162.

DOI:

https://doi.org/10.25077/ibioua.3.4. $\% 25$ p.2014

Bewley, J.D. \& Black, M. (1982) Physiology and bio-chemistry of seeds in relation to germination. 2nd edition, Springer-Verlag press.

Budiman, S., \& Desi, S. 2010. Berkebun Stroberi Secara Komersial. Jakarta :Penebar Swadaya.

Demirsoy et al., 2010. Seed treatment with GA3 or stratification enhances emergence of some strawberry tree genotypes - Short communication. DOI:

https://doi.org/10.17221/28/2009HORTSCI

Rusmin, D., Suwarno, F.C., \& Darwati, I . 2011. Pengaruh pemberian $\mathrm{GA}_{3}$ pada berbagai konsentrasi dan lama imbibisi terhadap peningkatan viabilitas benih purwoceng. Jurnal Littri 17 (3). ISSN 0853-8212. http://perkebunan.litbang.pertanian go.id/dbasebun/asset dbasebun/Pe nerbitan-20141207185425.pdf

El Hamdouni, E.M.; Lamarti, A.; Badoc, A. 2001. In vitro germination of the achenes of strawberry (Fragaria $\mathrm{x}$ ananassa Duch.) cvs 'Chandler' and "Tudla”. Bull. Soc. Pharm.

Bordeaux,140:

https://www.socpharm bordeaux.ass o.fr/pdf/pdf-140/140-031-042.pdf

Hancock, J.F. 1999. Strowberries. Crop production science in horticulture. USA: CABI Publishing.

Hanif, Z . 2015. Budi Daya Stroberi (Fragria X ananassa). Balai Penelitian Tanaman Jeruk dan Buah Sub Tropika. Batu, Malang. ISSN: 2319-7706 Volume 7 Number 03. http://balitjestro.litbang. pertanian.g o.id/budidaya-stroberi-fragaria- $\mathrm{x}$ ananassa/
Kucera, B., Cohn, M.A. \& Metzger, G.H. 2005 Plant hormone interactions during seed dormancy release and germination. Seed Science Res earch. 15:281- 307. https://doi.org/10.1079/SSR200521 $\underline{8}$

Lata, S., Sharma, G. Garg, S. \& Joshi, M. (2018). Effect of Different Chemical Treatments on Germination of Strawberry Seeds. International Journal of Current Microbiology and Applied Sciences. 7.

DOI:

https://doi.org/10.20546/ijcm as.20 $\underline{18.703 .150}$

Wilkins, M.B. 1978. The Physiology Of Plant and Development. Tata Mc Graw-Hill Publishing Co.LTD. New Delhi.

Zebrowska, J \& Hustynsky, J. 2002. Plant regeneration from leaf explants in strawberry (Fragaria $\mathrm{x}$ annanassa Duch.). Acta Horticulturae 567 (567):313-315. DOI: https://doi.org/10.17660/ActaHorti c. 2002.567 .66 